\title{
After the Revolution: Paul Samuelson and the Textbook Keynesian Model
}

\author{
Kerry A. Pearce and Kevin D. Hoover
}

\section{The Keynesian Revolution and Normal Science}

Thomas Kuhn's (1962) famous description of the development of science as radical revolutions followed by periods of steady elaboration of the revolutionary paradigm may not be the key to understanding scientific history or epistemology. It is nonetheless a useful heuristic. Revolutions are, of course, exhilarating; and, even in the historian's backward gaze, they command the most attention. Yet they are only half of Kuhn's conjugate pair, and normal science-the development and elaboration of the revolutionary paradigm-itself demands some attention.

The idea of the scientific revolution long predates Kuhn. Keynes sought self-consciously in The General Theory of Employment, Interest and Money (1936, v-viii) to stand traditional economics on its head, and early interpreters agreed that that was just what he had done. Lawrence Klein's interpretive book was entitled The Keynesian Revolution (1947). ${ }^{1}$ Klein represents an excellent example of the other of Kuhn's conjugates. After paying homage to Keynes the revolutionary, Klein embarked on

We thank the participants in the conference on New Perspectives on Keynes, and especially Allin Cottrell, Don Patinkin, and Robert Clower for comments on an earlier draft.

1. Of course, not all commentators on Keynes believed that his work was revolutionary, even if they found it important. Hansen (1936a) initially argued that Keynes provided no new foundation for economics, although he soon altered his view (Hansen 1938). Hicks ([1937] 1967) saw Keynes as a special case of a general theory that nested both the classical and Keynesian models-hardly the stuff of revolution. 
a classic career of normal science. He applied the (also new) tools of econometric analysis to the empirical implementation of the Keynesian model; the final results of which were the Federal Reserve-SSRC-Penn econometric model of the United States and Project LINK, which attempts to connect national macroeconomic models into a global macro model. Although Klein won the Nobel Prize for this work, it was not itself a revolution; for, as we tell our students, the beating heart of every major macroeconometric model is a little IS-LM model.

Elaboration of the paradigm is not all there is to normal science, however, just as important is the way in which normal science enforces and maintains its norms. One method of doing this is to establish a canon. The canon, however, comprises original texts that are rooted in the context of lively debate. Their authors may have been giants, but they were fallible nonetheless. To the degree that the canonical texts are seen as the contingent products of people, times, and places, they are subject to fundamental revision. Normal science can keep the student and practitioner on the straight and narrow if there develops an interpretive tradition that makes it unnecessary to consult the canonical texts with all their ambiguity, passion, and contingency. The development of textbooks is a hallmark of that interpretive tradition. Teachers of economics sometimes complain that, pedagogical style apart, current economics textbooks are almost all alike. This should be no surprise, for vis-à-vis normal science, that is exactly the point.

The existence of canonical textbooks is a considerable part of what distinguishes economics from other social sciences. In this article, we offer a preliminary history of the development in economics of the textbook tradition (a key aspect of normal science). Our history is told mostly through the work of Paul Samuelson, in particular through the successive fourteen editions of his Economics, first published in 1948. And who better? For among economists, Samuelson is Mr. Science. He is widely credited with establishing the scientific ideal in economics at the graduate and professional level with his 1947 Foundations of Economic Analysis. ${ }^{2} \mathrm{He}$

2. Weintraub 1991, chap. 3 describes the scientific mileau in which Foundations was conceived, particularly Samuelson's debts to physicist and statistician E. B. Wilson and population biologist A. J. Lotka. Boland 1989 argues plausibly that it is Samuelson's methodological approach to economics, one dominated by his understanding of the essence of scientific method in the late 1930 s and early 1940 s, that enjoys the practical allegiance of the economics profession, despite the attention and lip service paid to Milton Friedman's 1953 "Methodology of Positive Economics." 
takes pride in being a scientist: much of his life's work is gathered under the title The Collected Scientific Papers of Paul A. Samuelson (1966-86; emphasis added). The citation for his Nobel prize in Economic Science (to quote its correct title) reads in part: "for scientific work through which he has developed static and dynamic economic theory and actively contributed to raising the level of analysis in economic science" (Lindbeck 1985,40 ).

History is about what it was like then and how it became what it is like now. What we offer here is a history of the normal science embodied in the Keynesian economic model in the Principles textbooks since World War II. We emphasize process. It is important to understand at the outset that, in keeping with our theme of normal science, this is the history of the "hydraulic" (Coddington's 1983 [chap. 6, sect. 3] term) or "bastard" (Robinson's 1962 term) Keynesian model; it is (in Leijonhufvud's 1966 famous distinction) Keynesian Economics and not the Economics of Keynes. Futhermore, our concern is exclusively with the American textbook tradition, and not with how things have developed in Britain or elsewhere.

\section{Then and Now}

These disclaimers aside, it is easier to understand the story if we know where we are starting from and where we are going. To identify the starting point, it is useful to consider the main points of The General Theory as summarized, for example, in its chapter 18 (or in Keynes 1937). The key features are (a) the aggregative framework represented in the $Y=C+I$ or $I=S$ relationships (this was a triumph of rhetoric, avoiding many of the thornier controversies of the early 1930s with carefully chosen definitions; cf. Hansen 1936a); (b) the distinction between the monetary and the barter economy that is embodied in the rejection of Say's law and the existence of independent aggregate supply and aggregate demand curves; which (c) depended in turn on an analysis of labor markets in which, without further market imperfections, workers could be involuntarily unemployed whenever aggregate demand was deficient; and given (d) the marginal propensity to consume less than one, which implies the multiplier, aggregate demand would be deficient in fact, unless other spending, principally investment or government capital expenditure filled the gap; investment depended upon the comparison of (e) the marginal efficiency of capital with the rate of interest, which in turn was 
determined by the interaction of monetary policy and (f) liquidity preference; given the state of $(\mathrm{g})$ expectations, upon which both the marginal efficiency of capital and liquidity preference depended, investment might be insufficient to hold aggregate demand at a level high enough for full employment; a deficiency that could be made up for by (h) programs of government capital expenditure.

It is striking how successful the Keynesian agenda has been in one form or another in the textbooks. The latest edition of Samuelson's Economics (the fourteenth, now coauthored with William Nordhaus) is organized around these key Keynesian points. This is also true of virtually all macroeconomics textbooks. ${ }^{3}$ In addition to the main features of The General Theory, Samuelson and most other textbooks on economic principles and intermediate macroeconomics today also include features unknown to Keynes, the two most prominent being Okun's law and the Phillips curve.

It was not always like this, however. The textbooks of 1948 were not dominantly Keynesian, and even Samuelson's (1948) first edition was not tightly structured around Keynes's own conceptual framework. How then did the textbooks of the 1940s evolve into the textbooks of 1994? Our view is that this process represents a taming of the Keynesian revolution. While The General Theory was a theoretical rather than a policy-oriented book, its underlying motivation was to bring intellectual coherence to a family of antidepression policies that had already been widely supported on pragmatic grounds (see Clarke 1988). The Keynesian revolution in practice was both a revolution in policy and in theory. By 1994, however, the policy revolution had essentially been forgotten, and the analytical framework could be regarded as essentially neutral: it was adequate for the analysis of any sort of policy. The ubiquity of the Keynesian framework is underlined by the small number of obvious exceptions: Miller and Upton's (1974) Macroeconomics: A Neoclassical Introduction and Barro's (1993) Macroeconomics are true dissenters. The taming of the Keynesian revolution by the normal science of textbook Keynesianism begins with Samuelson's first edition in 1948 (S1-1948). ${ }^{4}$

3. Baumol and Blinder 1991, Lipsey et al. 1993, McConnell 1987, to name a few of the principles books; Dormbusch and Fischer 1994, Gordon 1993, Hall and Taylor 1993, to name a few of the intermediate macroeconomics books.

4. Hereafter the editions of Samuelson's Economics will be indicated by S[edition number][publication date] 


\section{The Problem of Keynesian Interpretation: The Search for a Model}

Revolutions do not resolve into normal science without a period of turmoil and confusion. The decade after publication of The General Theory was such a period. To understand the environment in which Samuelson's first edition was launched, we must briefly consider the history of this period.

Was Keynes a revolutionary? If so, what was the nature of the revolution? These questions animated the debate over The General Theory from the beginning. A prior question was the nature of Keynes's contribution: Was it to economic theory or to economic policy? The General Theory was widely reviewed in the United States, not only in economics journals but also in serious popular magazines such as the Saturday Review and The Nation. Reactions were mixed. On the one hand, it received a number of favorable reviews (Franklin 1936; Hardy 1936) that praised its freshness, consistency, and lack of the arrogance typical of the heterodox economist. Other reviewers thought it seriously incomplete (Stewart 1936; Taylor 1936). Writing in The New Republic, Taylor opined that "the General Theory will not add directly to [Keynes's] popular prestige" because it was written in "a highly abstruse and mathematical fashion" (1936, 349). Alvin Hansen opens his famously negative review by applying to The General Theory Keynes's own words from a review of J. A. Hobson's Gold, Prices and Wages: "This book is . . . made much worse than a really stupid book could be, by exactly those characteristics of cleverness and intermittent reasonableness which have borne good fruit in the past" $(1936 a, 667)$. Later in the review Hansen writes:

The book under review is not a landmark in the sense that it lays a foundation for a 'new economics.' . . . The book is more a symptom of economic trends than a foundation stone upon which a science can be built. . . . It is reasonably safe to predict that Keynes's new book will, so far as his theoretical apparatus is concerned, fare little better than did the Treatise on Money. (686)

Hansen grasps the main lines of The General Theory and sees Keynes's as a contributor to economic theory, albeit not a revolutionary one. Indeed, he argues that Keynes's theory "is not tenable except upon 
the assumptions of an approach to a rigid economy in which costs are highly inflexible and supplies monopolistically controlled" (Hansen 1936b, 829).

Other commentators saw Keynes as a revolutionary in the matter of economic policy, but were skeptical: "The ideas put forward by Keynes would entail a revolution in power and property, but we can hardly believe that mankind will accept a new economic and social set-up by persuasion" (Lederer 1936, 487).

The dual aspect of Keynes's revolution remained in the American debate for some time. Famous in his rejection of Keynes, Hansen became yet more famous for his Pauline conversion to Keynesianism. By the time his review of Keynes from the Journal of Political Economy (Hansen 1936a) was reprinted, he had removed the passages most damning of Keynes's theoretical achievement (Hansen 1938, 34). The Oxford symposium of 1936 - which led to the famous interpretive papers of Harrod, Meade, and Hicks (see Young 1987, chap. 1, esp. pp. 12-38)—was critical. Hansen was greatly influenced by Hicks, calling his contribution "brilliant" (Hansen 1949, 71). In Young's $(1987,115)$ word, his series of proselytizing books (Hansen 1949, 1951, 1953) "institutionalized" Hicks's SI-LL diagram under the now standard name of IS-LM. Hansen effectively joined the theoretical and the policy aspects of the Keynesian revolution, showing how the IS-LM apparatus could be used for policy analysis. While this established a major interpretive tradition eventually to become the core of textbooks in intermediate macroeconomics, it took a long time to become the standard analysis. Hansen's work remained for some time part of revolutionary faction rather than the foundation of normal science.

The interpretive approach, of which the IS-LM model was a part, also formed the basis for another aspect of the development of Keynesian economics. In America, Modigliani 1944 and Klein 1947 (appendix) formalized the Keynesian model in a manner very close to that of Hicks [1937] 1967. As observed above, this was the beginning of the program of Keynesian econometrics. Klein also made a first attempt at deriving the key Keynesian functions from the behavior of individual economic actors-an early contribution to the program of microfoundations for macroeconomics that was developed in the work of Clower 1965, Friedman 1957, Patinkin 1956, Tobin 1958, and others. This program, too, may be seen as ultimately the working out of normal science, but in its beginnings it remained mired in debates over the true meaning of The 
General Theory and over which assumptions and specifications were necessary to obtain essential Keynesian conclusions such as the existence of involuntary unemployment.

Whereas for Hansen Keynes heralded a theoretical revolution (at least as he was interpreted by Hicks), for Abba Lerner it was the Keynesian policies that were revolutionary. Lerner used his own theoretical insights to promote Keynesian policies. He clarified the paradox of thrift, showing how the sense of paradox arose from a fallacy of composition (Scitovsky 1984,1556 ). He pioneered the macroeconomics of rigid wages and prices. He showed that for a decrease in wages to stimulate employment, wages and prices would have to fall instantaneously and to the full extent needed to return the economy to full employment. Lerner points out that this perfect flexibility is incompatible with a monetary economy (Scitovsky 1984, 1558).

Lerner's theory of functional finance met with stiff resistance at first, but it soon became accepted as the clearest representation of Keynesian policy prescriptions (Scitovsky 1984, 1561). David Colander aptly observes:

What eventually became known as textbook Keynesian policies were in many ways Lerner's interpretations of Keynes's policies, especially those expounded in The Economics of Control (1944) and later in The Economics of Employment (1951). . . . Textbook expositions of Keynesian policy naturally gravitated to the black and white 'Lernerian' policy of Functional Finance rather than the grayer Keynesian policies. Thus, the vision that monetary and fiscal policy should be used as a balance wheel, which forms a key element in the textbook policy revolution, deserves to be called Lernerian rather than Keynesian. $(1984,1573)$

By 1948 , the Keynesian revolution in the upper reaches of the economics profession was stabilizing around a rich hydraulic Keynesianism: the IS-LM model on the theoretical side and Lerner's analysis on the policy side. Elementary textbooks did not settle down so easily. Keynesian ideas entered them in bits and pieces.

The attitude of textbook writers before 1948 is summarized in a characteristic remark from one of them:

Whether we agree fully with the Keynesian theory or not, and regardless of whether we accept the practical measures to meet the prob- 
lem of unemployment that are offered by Keynes and Hansen and their followers, we cannot afford to ignore the impact upon traditional economic theory which has been made by the theory of savings and investment. ${ }^{6}$ (Meyers 1948, viii)

The "impact" of Keynes is shown in the coverage his ideas receive in texts. In Meyers's last edition of Elements of Modern Economics (1948), the chapter on saving, investment, and employment (chap. 25) is based mainly on The General Theory, although "many of the statements . . . are not in strictly Keynesian terms" (396n). Meyers's book adopts the Keynesian national accounting scheme, permits equilibrium with underemployment, and uses liquidity preference to help determine the interest rate. Missing, however, are key pieces of the Keynesian model: the marginal propensity to consume, the consumption function, and the multiplier.

The quotation from Meyers's textbook is instructive: Keynes is being absorbed into American textbooks at one remove, and Hansen is a primary transmission mechanism. But just as Hansen's reaction to The General Theory in his more advanced work underwent a transformation, so did his treatment of Keynes in his elementary textbook. In the second edition of Principles of Economics, Hansen and his coauthor Frederic Garver teach the classical approach of Say's law: "The monetary and credit facilities of a country usually find in the long run reasonably full employment" (Garver and Hansen 1937, 333). The only mention of Keynes is in the chapter on business cycles, and this is just a passing reference: "A long list of writers, including Spiethoff, Wicksell, Robertson, and Keynes, have advanced the view that the essential characteristic of the business cycle is the fluctuation in investment in capital goods" (363).

Garver and Hansen's third edition (1947) is somewhat more Keynesian, but even it is incomplete. It focuses mainly on the Keynesian accounting scheme, mentioning the marginal propensity to consume and the multiplier only briefly. It does, however, completely adopt the Keynesian view that the price level is better explained through "aggregate demand" or "income theory" than through a Fisherine quantity equation (233-36). Nevertheless, it is only in Hansen's later textbooks $(1949,1951,1953)$ that a complete Keynesian model is present.

6. The earlier, second edition of this text (Meyers 1941) had not contained any discussion of Keynesian theory. 
Other textbooks are selective in their use of Keynesian analysis. Benham and Boddy adopt a single Keynesian tool: a liquidity-preference function. They argue that Keynes's (and Hansen's) analysis is, in the main, an "economics of slump," believing themselves "that something approaching full employment can and will be achieved" $(1947,10)$.

Although borrowing more from the Keynesian toolkit (underemployment equilibrium, the propensity to consume, the paradox of thrift, and liquidity preference), John Ise's Economics $(1950,406)$ also denies the generality of Keynes's analysis, calling Keynes the leader of "depression economists" and confining systematic Keynesian analysis to a single chapter. In contrast, Valdemar Carlson's An Introduction to Modern Economics (1946), is more favorable to Keynes, though still incompleteand still filtered through Hansen. Carlson uses some Keynesian terminology and advocates some Keynesian policies, and he sees effective demand as the key to unemployment policy. He argues that once full employment is achieved, public policy can attempt to increase investment to combine with consumption to maintain full employment. Alvin Hansen is Carlson's main source, not Keynes himself.

While many textbooks found the essence of Keynes in his treatment of aggregate demand, most adopted only selected elements of Keynesian analysis. At the same time, a largely separate struggle to incorporate a Keynesian analysis of aggregate supply into textbooks was under way. King observes that a large part of the reason for debate about aggregate supply was that Keynes

did not provide a diagrammatic exposition of his argument. . . . Had he done so, however, it would have been in $Z, N$ space, where $Z$ represents aggregate proceeds (realised or expected), and $N$ the level of employment. Keynes's aggregate supply and demand curves clearly would not have been drawn in $P, Q$ (price level-quantity of output) space, as in modern textbooks. But aggregate supply and demand lay at the core of Keynes's analysis. $(1993,4)$

Fifteen years after publication of The General Theory, confusion still reigned about aggregate supply and demand. The lack of a consensus view on the treatment of aggregate supply is reflected in the differences in diagrammatic presentation. Different articles and monographs mapped on the vertical axis, variously, individual price, the money value of expenditure, the real value of expenditure, and the aggregate price level and on the horizontal axis, variously, individual output, aggregate employ- 
ment, the real value of aggregate output, and the money value of aggregate output (King 1993, 32). Only relatively late, in Joseph McKenna's Aggregate Economic Analysis (1955) does the aggregate supply curve appear in something close to the form common in modern textbooks.

Lorie Tarshis's Elements of Economics (1947) is often regarded as the first systematically Keynesian textbook (see Blaug 1991, 74). Tarshis's book was a self-conscious break with the contemporary textbook tradition; it identified The General Theory as its major inspiration, placing a greater emphasis on the determination of national income than on the theory of distribution (Tarshis 1947, x, 346). Tarshis includes the essential elements of the Keynes's agenda, but he rejects the view that Keynes provides only the economics of the slump, carefully distinguishing between the beneficial employment effects of aggregate demand expansion below full employment and its inflationary and distributional effects at full employment (475). He also moderates the policy aspects of the Keynesian revolution: "To conclude that an increase in public investment would bring about a rise in employment does not necessarily mean that we should endorse that remedy" (518; cf. 499). Thus, Tarshis's book was a systematic Keynesian textbook, but it did not capture the hearts and minds of the economics teacher. It did not succeed in "normalizing" the new Keynesian science of macroeconomics because it remained too close to Keynes's canonical text. It was more like the exegetical commentaries, main debating tools of the scholastics, that remind the reader that interpretation of the canonical text was up for grabs, than like the pedestrian primer that makes the reader wonder how there could ever have been a passionate debate in the first place.

Another book that was Keynesian in its outlook was the second edition of Kenneth Boulding's Economic Analysis (1948). Like Tarshis's textbook, Boulding's book reminds the reader that Keynesian concepts are still elements in debate and are still held tentatively subject to further analysis and discovery. Boulding, for example, uses an aggregate supply and demand diagram in PQ space, but he uses it to point out the dangers of aggregative thinking, arguing that if one tries to draw supply and demand diagrams for output as a whole, "no solution is possible" (262).

Textbooks like those of Tarshis and Boulding in some sense repre-

7. Elzinga $(1992,864)$ suggests that Samuelson's textbook had a "second-mover" advantage, Tarshis's book having paved the way for it and having drawn hostile responses that would inevitably meet the first Keynesian textbook. 
sented a high-water mark in the influence of Keynes on elementary economics, but they remained part of the Keynesian revolution and were unable to ensure a "return to normalcy." For that, students had to wait for Samuelson's Economics.

\section{Samuelson's First Edition: Bastard Keynesianism or Virgin Birth?}

Samuelson's Economics succeeded in establishing normal science where earlier textbooks had failed in large measure because, unlike the authors of those earlier books, Samuelson did not attempt to explicitly and faithfully reproduce Keynes's ideas. Joan Robinson labeled hydraulic Keynesian models as "bastards," a term that suggests they are the product of an irregular liaison. In the case of Samuelson, however, it may be closer to the mark to absolve Keynes of paternity altogether. In some sense, Samuelson's macroeconomic model is the product of a virgin birth. As with the more famous story of Jesus, the birth of Samuelson's model is more complicated.

Keynes is the Joseph of the story. For just as Jesus was careful to identify himself as a branch of Jesse's tree, as a true member of the House of David, Samuelson's model is called Keynesian, though it bears a highly circumscribed relation to The General Theory. ${ }^{8}$ In Samuelson's first edition, there are only two references to Keynes-and neither is truly substantial. The connection to Keynes is invoked without the details of Keynes's analysis, and Samuelson's first edition does not make reference to the rich interpretative tradition of the years between 1936 and 1948. He does not mention Hicks, Hansen, Meade, or Harrod; nor does he mention Tarshis, Boulding, or the other textbook writers.

The core of the macroeconomic model of the first edition of Economics is the 45-degree diagram frequently known as the "Keynesian cross." This diagram does not appear in The General Theory, and Samuelson's

8. Our metaphor should not be misunderstood. We do not mean to imply that the content of Samuelson's book is antithetic or contrary to The General Theory or that Samuelson was ignorant of Keynes. In calling Samuelson's model a virgin birth, we instead wish to stress that identification with a Keynesian school of thought was a secondary consideration for Samuelson, and that the development of his model was not substantially constrained by considerations of fidelity to Keynes's intentions, exposition, or method. Samuelson serves the god of economics, not the law of Keynes. Don Patinkin has suggested to us that this attitude is an illusion due to the fact that writers of textbooks aim not at scholars but at students, and therefore rarely carefully document their sources. We do not believe this is an adequate explanation because, as we show presently, Samuelson's attitude is similar in his own scholarly work. 
use of it derives directly from his two papers on the interaction of the multiplier and the acceleration principle (Samuelson 1939a, 1939b). In these papers, the multiplier is mentioned in connection with Keynes, although the tone of the discussion suggests an idea that is just "in the air." The accelerator principle is also not Samuelson's own invention, but is taken by him to be a commonly accepted tool of the businesscycle literature. Samuelson himself appears to recognize that it is not Keynesian (1939b, 787). His own contribution is to explore the cyclical properties of models containing both multipliers and accelerators. ${ }^{10}$

To begin his analysis, Samuelson first considers "the position of the equilibrium state which, if established, would maintain itself and around which all oscillations take place." Without any induced investment, the stationary level of income must be that which businesses "receive back from consumers the whole amount which they pay out to factors as costs of production" (1939b, 789-90). This is illustrated in the 45-degree diagram as the intersection between the typical consumption function and a 45-degree line. When net investment is included, the level at which income can remain stationary is higher. This is shown in the diagram by raising the consumption function to cross the 45 -degree line at a higher level of income. "There is, of course, no reason why the stationary equilibrium level could not be very near the level of full employment" (Samuelson 1939b, 791). The 45-degree diagram occupies a mere two pages in the article and is not used any further there. A decade later, the 45-degree diagram became the analytical core of Samuelson's first edition. To extend the sacred metaphor, we might think of the intervening years as its time in the carpenter's shop.

Samuelson's first edition, to be sure, has some characteristically Keynesian features. The accounting system, $\mathrm{Y}=\mathrm{C}+\mathrm{I}+\mathrm{G}$, forms the backbone of the book." As he puts it, "national income provides the central unifying theme of the book" (S1-1948, v). The marginal propensity to con-

9. Whether or not the analysis underlying the 45-degree diagram is to be found in Keynes is hotly debated (see Davidson 1989; Fusfeld 1985; Patinkin 1989). We are inclined to agree with Patinkin and with Allin Cottrell, our discussant at the conference on New Perspectives on Keynes, that the Keynesian cross is a rendering of a simplified analysis of the macroeconomy found in The General Theory (especially chap. 3). However, as noted in note 8 above, Samuelson's use of it is detached from its Keynesian roots.

10. Samuelson $(1939 \mathrm{a}, 75)$ credits the multiplier-accelerator model to Hansen.

11. Don Patinkin has pointed out that it is not to Keynes but to Colin Clark and Simon Kuznets that this accounting system is ultimately due. Nevertheless, it is clearly the system that Keynes adopts in The General Theory. 


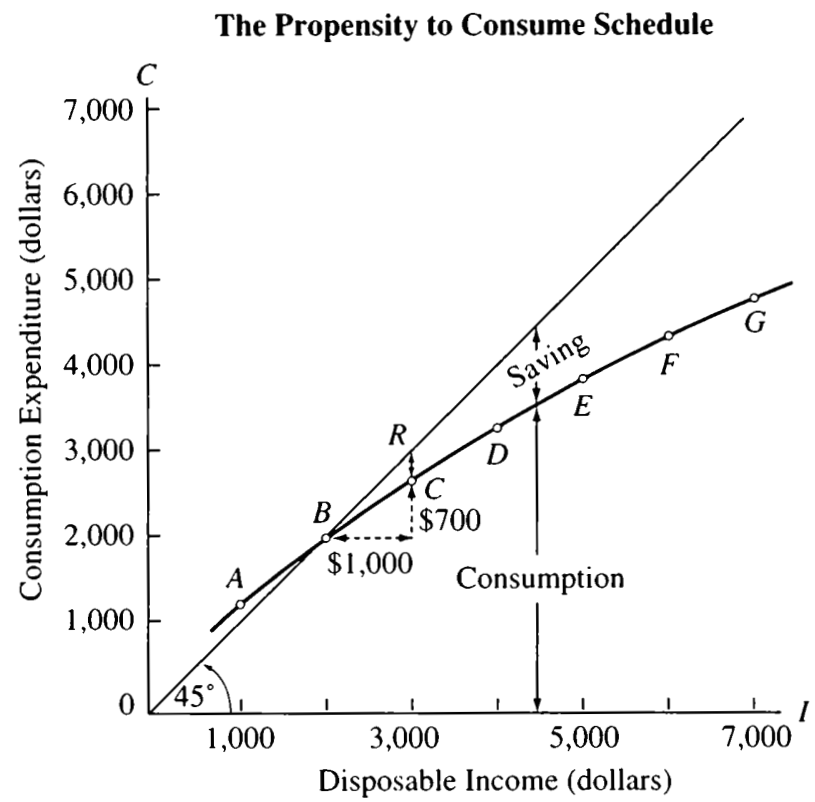

Figure 1 The 45-degree diagram for a single family (source: Samuelson's Economics, 1st ed., 1948, p. 210). This shows how consumption depends on family income.

sume and the multiplier are fundamental to the analysis of the 45-degree diagram. Samuelson constructs a propensity-to-consume schedule for a single family (see figure 1). The intersection of the propensity to consume (the consumption function) and the 45-degree line is called the "breakeven income" where families spend exactly what they make (S1-1948, 210).

From the analysis of the single family, Samuelson aggregates his model to provide the "modern theory of income analysis." He stresses that the level of total spending is determined by the interplay of the forces of saving and investment (S1-1948, 253). The propensity-to-consume schedules were previously developed in relation to "behavior of a typical family as it receives more or less income. Now we want to add up all the different family patterns to get the propensity-to-consume schedule for the whole community" (257). The system converges to equilibrium at the intersection of the propensity-to-consume and the 45-degree line. 
196 Kerry A. Pearce and Kevin D. Hoover

The Consumption and

Saving Schedules

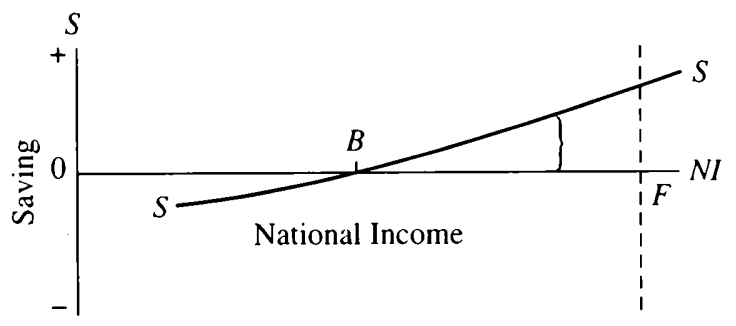

(a)

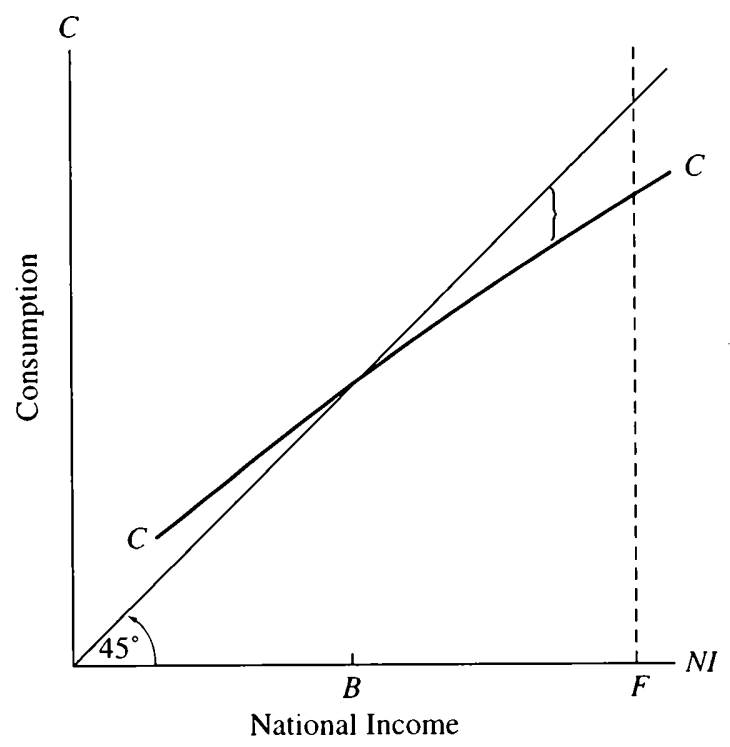

(b)

Figure 2 The 45-degree diagram for the community (source: Samuelson's Economics, 1st ed., 1948, p. 258). In these propensity-to-save and propensity-to-consume schedules, the vertical distances shown by brackets are equal. 
The analysis is presented graphically (see figure 2) and verbally-but not algebraically.

Samuelson elaborates the basic 45 -degree model. The multiplier is introduced verbally, then presented graphically using the diagram. Thereafter Samuelson models investment as dependent on national income and discusses the paradox of thrift, the idea that an increase in thriftiness may cause a deeper depression. To disentangle the paradox, he appeals to two considerations: first, he notes the problem of the fallacy of composition-an individual increases personal savings with greater thrift, but in aggregate this need not be so because income adjusts; second, the paradox is restricted to situations below full employment (S1-1948, 270): "If output could be assumed to be always at its maximum, then the old-fashioned doctrine of thrift would be absolutely correct" (271). In advocating the soundness of the paradox of thrift, Samuelson at the same time underwrites the Keynesian denial of Say's law.

Samuelson faithfully relates Keynes's theory of liquidity preference as part—but only a part—of the determination of interest rates (S1-1948, 304). Samuelson acknowledges that interest rates may be depressed by expansionary monetary policy and that investment may be stimulated by the lower rates, but he puts little store in the mechanism and does not integrate the discussion of money with the discussion of income determination. Money is a fifth wheel in Samuelson's model: "Today . . . we no longer hold out high hopes for effectively maintaining full employment and high production by means of Federal Reserve monetary policy" (338). Perhaps, Samuelson says, monetary policy is ineffective because of the existence of excess reserves. Open-market purchases may serve only to increase excess reserves, with the action ending there. Monetary policy cannot be used to dampen the business cycle: "An expansionary monetary policy may not lower effective interest rates very much but may simply spend itself in making everybody more liquid" (353).

Key features of Keynes's analysis are missing in Samuelson's first edition. While Samuelson acknowledges an underemployment equilibrium and discusses money in the detached manner already noted, he does not seriously consider the difference between the real and the monetary economy. The core 45-degree model is a real one in which monetary factors play no role. Samuelson's investment analysis appeals to the acceleration principle-a non-Keynesian idea-and, even here, the context is his discussion of the theory of business cycles. The acceleration principle 
is connected to the 45-degree diagram only indirectly: "We may be in a vicious circle whereby the acceleration principle and the multiplier interact so as to produce a cumulative deflationary (or inflationary) spiral" (S1-1948, 407).

A checklist of Keynesian features-present or absent-does not do justice to Samuelson's achievement. His Economics is above all a harmonist book. The core model continues in its sanctified role as the Prince of Peace among competing economic doctrines. The foundations of the peaceable kingdom are, above all, in scientific economics. Students of economics are encouraged to become scientists: "At every point of our analysis we shall be seeking to shed light on . . policy problems. But to succeed in this, the student of economics must first cultivate an objective and detached ability to see things as they are, regardless of his likes or dislikes" (S1-1948, 5).

Science, for Samuelson, is not just a matter of naive realism; it also relies on a neutral and generally applicable analytical framework: "The important thing is to provide the analytical machinery that will enable the reader to arrive at, and defend, his own opinion, and, what is hardly less important, to understand the position of those with whom he most disagrees" (S1-1948, vi). With this in mind, Samuelson sets out the course of study: "The first task of modern economic science [is] to describe, to analyze, to explain, to correlate these fluctuations of national income" (4). Once this is done,

the important hard kernel of truth in the older economics of full employment can then be separated from the chaff of misleading applications. Moreover, as we shall see later, if modern economics does its task well so that widespread unemployment is substantially banished from democratic societies, then its importance will wither away and traditional economics (whose concern is wise allocation of fully employed resources) will really come into its own-almost for the first time. (10)

Samuelson's analysis thus reconciles the competing economics of Keynes and the classics - establishing a heaven of economic analysis on earth by attacking the original sin of slack resources. ${ }^{12}$

12. Allin Cottrell reminds us of a passage in The General Theory (378-79) that is remarkably like the quotation from Samuelson. As we show in the next two paragraphs, however, the relationship between the Keynesian and classical analysis is much more policy-oriented, and therefore more Lernerian, than Keynes's own analysis. 
In the first edition, the harmony that Samuelson establishes is not a harmony of a very general analytical apparatus in which Keynesian and classical economic analysis appear indifferently as special cases. His harmony is one in which positive policy actions must cure the imperfections of the economy, removing the special circumstances in which Keynesian analysis is essential and establishing the special circumstances in which classical analysis is informative. In keeping with our metaphor, a demanding ethics is required of Samuelson's believer. The difficulty that economics must face, in Samuelson's view, is that there is no guarantee "that there will be just exactly the required amount of investment to ensure full employment: not too little so as to cause unemployment, nor too much as to cause inflation" (S1-1948, 255). Samuelson appeals to Abba Lerner's analogy of the economy as "a system without a steering wheel" (S1-1948, 255; cf. 407-9).

Samuelson advocates fiscal policies that aim to supply the missing "governor" or "steering mechanism" for the economy. Fiscal policy has two main goals: countering the business cycle and providing secular stimulus. Samuelson advocates public works, welfare spending, and tax policy as countercyclical measures. He maintains that few people would object to the objects of countercyclical policy (S1-1948, 417). He is, however, frank about the difficulties of implementing it: difficulties of planning, timing, crowding out, and coordination between government bodies (especially coordination of state and local government with federal government). He regards policies for secular stimulus as far more controversial, noting that "many eminent economists are opposed to any policy of continuous deficits" (418).

While Samuelson's peaceable kingdom offers a truth available to advocates of different policy ends, it depends on particular policies itself. These might be described as moderately liberal. From such a standpoint, Samuelson is able to strike a neutral pose between extreme policies. Samuelson credits much of the modern income analysis to Keynes, but adds that "today its broad fundamentals are increasingly accepted by economists of all schools of thought, including, it is important to notice, many writers who do not share Keynes' particular policy viewpoints and who differ on technical details of analysis" (S1-1948, 253). Samuelson is quick to separate this analysis from the narrow definition of "Keynesian": "in the sense of belonging to that narrow band of zealots associated with some of the policy programs that Keynes himself espoused during the Great Depression" (254). 
Samuelson's pose of neutrality and detachment from Keynes's own policy positions is perhaps the essential first step in taming the Keynesian revolution and setting macroeconomics on the path of normal science. Samuelson is subsequently able to convert what might have been thought to be disputes about normative ends into technical disputes about scientific economics. He thus stigmatizes various monetary cranks: "Some monetary cranks think that this [leakage of] saving necessarily means unemployment and depression. Such a view is simply incorrect" (S11948, 263). "But there is also a second school of monetary cranks: they go to the opposite extreme and insist that saving and investment can never cause income to be too high or too low. . . It is only in the last few decades that economists have learned how to separate out the truth and falsity of both extreme viewpoints" (264). Keynes himself (1936, chaps. 23-24) found significant insights and inspiration in the imperfect analyses of monetary cranks such as Major Douglas and Silvio Gesell. He appreciated the linkage between their policy concerns and their attempts to formulate adequate understandings of the economy. His joint theoretical/policy revolution aimed in part to perfect the deficiencies of their analysis. Samuelson's technocratic dismissals of the monetary cranks underscores the extent to which he has moved beyond Keynes in normalizing macroeconomics.

Divine figures resolve paradoxes by embracing them. Samuelson's Economics presents the neoclassical microeconomics of resource allocation and, simultaneously, the Keynesian economics of underemployment. Samuelson's advocacy of full employment policies may in a practical sense serve his liberal politics, but its analytic goal is to resolve the paradox between Keynes and the (neo-)classics. This is accomplished through studied vagueness. There is no serious attempt to reconcile the macroeconomics of his first edition with microeconomics; resolution of the paradox is then mostly an avoidance of its implications. The 45degree diagram is helpful in this regard: it is, at best, one piece of an analytical model, not a closed model in itself. The advantage of featuring such a model centrally is that it is easy to justify the need to add verbal qualifications and nuances to the analytical framework-as Samuelson constantly does-to make it speak to a wide range of issues without facing the problem of developing a model that is both internally consistent and informative about the world. The cost of this strategy is that Samuelson's model is not a closed system that could, for example, 
be developed into a full-scale econometric model, which is the fate of the richer hydraulic Keynesian models from IS-LM on.

\section{The True Church: The Developments of Samuelson's Later Editions}

Samuelson's Economics went through eleven editions in which he was the sole author; it remains in print (editions twelve to fourteen were coauthored with William Nordhaus). It is among the best-selling textbooks in any field. ${ }^{13}$ Principal features of Samuelson's text remain unchanged over a period of forty-six years. We have argued that Samuelson's "son" of Keynes was really the product of a virgin birth; it also appears true that, in common with other products of immaculate conception, the analytical apparatus of Samuelson's Economics has remained unsullied by its confrontation with the world. The larger uses of that apparatus have also remained unchanged: Samuelson of the eleventh edition remains the harmonist and neutral scientist of the first edition. Maintaining neutrality is a difficult business that must be actively pursued. Over five decades, Samuelson has had to respond to various challenges, so that subsequent editions are considerably different from the first. The church has history, despite the constancy of its core doctrine.

As we observed already, in the first edition, Samuelson had sought to explicitly identify his macroeconomic analysis with Keynes, while nonetheless distancing it from the particular policies Keynes advocated in the 1930s and the subsequent policy positions of Keynesian "zealots"; at the same time, he argued that proper policies would underwrite the relevance of classical allocation theory. In subsequent editions, Keynes becomes increasingly deemphasized and the harmonist ideal becomes more prominent. In the second edition, Samuelson writes:

In recent years, 90 per cent of American economists have stopped being "Keynesian economists" or "anti-Keynesian economists." Instead they have worked toward a synthesis of whatever is valuable in older economics and in modern theories of income determination. The result

13. Data in Elzinga (1992, table 3) show that up to 1984 Samuelson's Economics had cumulative domestic sales of $3,031,499$, just greater than those of the various editions of McConnell (1987). But McConnell's textbook first appeared twelve years after Samuelson's, and outsold it in most of the years after 1966. 
might be called neo-classical economics and is accepted in its broad outlines by all but about 5 per cent of extreme left-wing and right-wing writers. (S2-1951, 260)

By the third edition, Samuelson has coined one of the most famous phrases in the history of macroeconomics and underscored his harmonist aim in salvationist terms: ${ }^{14}$

Repeatedly throughout the book I have set forth what I call a "grand neoclassical synthesis." This is a synthesis of (1) the valid core of modern income determination with (2) the classical economic principles. Its basic tenet is this: Solving the vital problems of monetary and fiscal policy by the tools of income analysis will validate and bring back into relevance the classical verities. This neoclassical synthesis does something equally important for the teaching of economics. It heals the breach between aggregative macro-economics and traditional micro-economics and brings them into complementing unity. $(\mathrm{S} 3-1955, \mathrm{vi})^{15}$

The ornaments of Samuelson's Economics shift with the times in complicated ways. In the first edition, he claims-without closely justifyingKeynesian roots, but he refers most frequently to his macroeconomics simply as "modern theories of income determination." In contrast, the chapter on income theory in the seventh edition begins with the quotation from Milton Friedman: "We are all Keynesians now" (S7-1967, 195). Rather than taking partisan satisfaction in Friedman's concession, Samuelson restates his ideal of scientific neutrality: "Modern economists are 'post-Keynesians,' keen to render obsolete any theories that cannot meet the test of experience" (196). Later in this edition, however, he stoops to conquer, adopting "Keynesian income theories" in place of "modern income theories" as his preferred terminology (581). This change was probably driven by the resurgence of the quantity theory

14. The third edition, along with the first and seventh, are the ones that Samuelson himself regards as his "vincage" editions (Samuelson S9-1973, ix).

15. A well-known story attributes Samuelson's coinage to his desire to appear less "pink" during the McCarthy era. Samuelson himself lends credence to the story with his discussion of the effect of McCarthy on the economics profession in his introduction to the fourteenth edition. Furthermore, both Samuelson and Tarshis were among those assailed from the right (see for example, William F. Buckley's attack on the economics department at Yale in his famous God and Man at Yale (1951, chap. 2) in which the textbooks of both authors figure prominently). 
of money and the need, for the first time in two decades, to distinguish between competing analytical apparatuses. Over time, the terminology "neoclassical synthesis" is deemphasized, although the goal it represents remains central. By the seventh edition, Samuelson instead refers to the "new economics," while noting that it is not new or different, but simply the macroeconomics he has advocated through the previous six editions of Economics (S7-1967, vi). ${ }^{16}$

The shifting terminology of the seventh edition suggests that Samuelson's analytical apparatus was, by the mid-1960s, subject to two different pressures. On the one hand, he had sought from the first edition on to reconcile microeconomics and macroeconomics through application of policies that assured full employment and effectively created the conditions under which Say's law would apply. On the other hand, the analytical apparatus itself was subject to challenge from alternative approaches to macroeconomics. These two challenges are, of course, not independent. The policy problem of maintaining full employment originally suggested the neoclassical synthesis. The emerging problem of inflation in the 1960s encouraged the development of alternative analytical frameworks such as Friedman's restatement of the quantity theory. Nevertheless, to the degree that the challenges were analytical, the maintenance of a neutral, scientific, and harmonist macroeconomics required a different tactic. Samuelson had to argue now for the generality of his analytical framework, for its ability to nest competing views as special cases. Let us now consider the development of his framework as a response to the challenges of policy on the one side and of competing theoretical frameworks on the other. Like the church, Samuelson's analytic framework had to adapt to modern conditions and to confront the forces of schism and reformation.

In the first edition of Economics, the national accounting scheme had been central and the 45 -degree diagram was modestly displayed. By the second edition, "the national income approach has been retained, but it has been subordinated to the over-all goal of synthesizing aggregate concepts with economic analysis of the component parts" (S2-1951, vi). The

16. In the eighth edition, Samuelson refers to the "post-Keynesian neoclassical synthesis" (S8-1970, 309). By the ninth edition, Samuelson has begun to treat the neoclassical synthesis as principally a chapter in the history of economic thought: "Just a century ago the tree of economics bifurcated. One branch led through neoclassical economics and Keynesian economics to the present-day era of post-Keynesianism" (S9-1973, 843). 
45-degree diagram provides the skeleton upon which these component parts are hung. Its importance is highlighted by the fact that it appears embossed on the cover of the book.

The policy concerns of the second edition are not just the avoidance of depressions. With a return to an economy that is obviously cyclical, an economy with both booms and slumps, Samuelson is more careful to use the model as part of a description of business cycles and as a guide to countercyclical policy. Monetary policy begins to be less of a fifth wheel as Samuelson now illustrates how cheap money lowers interest rates, stimulates investment-shifting the $\mathrm{C}+\mathrm{I}$ curve upward in the 45-degree diagram-and so produces a multiplied effect on national income (S2-1951, 343). ${ }^{17}$ To justify this sequence, Samuelson not only concedes to monetary policy a greater analytical role, but he also must move more in the direction of Keynes's own analysis of investment in terms of a comparison of the "marginal efficiency ('demand') schedule of investment" and an interest rate (S2-1951, chap. 29).

Having conceded the analytical role of money in income determination, the policy concerns of the hour continue to guide Samuelson's emphasis. In the fourth edition, he is careful to state that the investment function is likely to be nearly vertical in a deep depression, robbing monetary policy of its potency (S4-1958, 333). By the eighth edition, he notes that the research of Milton Friedman reinforces that of post-Keynesians such as James Tobin, Franco Modigliani, and himself who agree with Keynes-but not necessarily with some of his followers-that money matters very much (S8-1970, 310).

The shifting emphasis on the role of money is, in part, a response to the reorientation of policy concerns since publication of the first edition toward the problem of inflation. Samuelson's apparatus was not well adapted to the analysis of inflation: aggregate supply plays a very small role in his initial model, and there is no attempt to integrate price and wage determination into the 45-degree diagram. The discussion of the labor market, wages, and factors of production is largely restricted to the microeconomic sections of the book. The level of full-employment GNP is taken to be a datum. Demand insufficient to support full employment is described in terms of a "deflationary gap" that can be filled with additional

17. Patinkin 1983 provides a general overview of the development of Samuelson's thinking in monetary economics not restricted to his textbooks. 
investment, while demand in excess of full employment is reconciled by rising prices. Samuelson continues to use this analysis across the entire run of Economics. Yet, as inflation develops into the principal policy problem, its inadequacies became clearer. One difficulty is that the treatment of inflation and deflation is asymmetrical: deflationary gaps appear to provide definite answers about the level of unemployment and the shortfall of GNP; inflationary gaps result in rising prices and wages, but there is no definiteness about their levels or rates of change. A second difficulty is that Samuelson becomes convinced over time that factorcosts have become an important determinant of inflation. This is clear in the fourth edition where he distinguishes between "demand-pull" and "sellers" inflation (S4-1958, 335).

The fact that the 45-degree diagram was inadequate to the analysis of inflation probably explains the rapidity with which the Phillips curve was incorporated into Samuelson's Economics. Phillips's article on wage inflation and unemployment was published in 1958; Samuelson and Solow extended it to price inflation and used it for policy analysis in an article in the American Economic Review in 1960. And it appears in Economics for the first time in the fifth edition, published in 1961. Phillips's analysis had featured firms setting rates of change of nominal wages in response to the state of the labor market, the tightness or looseness of which was a product of demand pressures. Samuelson, however, considers the Phillips curve in the context of cost-push inflation in which firms set prices as a mark-up over factor costs. The Phillips curve presents the policy maker with a menu:

The indicated 'Phillips Curve' shows by its downward slope that increasing the level of unemployment can moderate or wipe out the upward price creep. There is, so to speak, a choice for society between reasonably high employment with maximal growth and a price creep, or reasonably stable prices with considerable unemployment; and it is a difficult social dilemma to decide what compromises to make. (S5-1961, 383)

Despite later criticisms from Phelps 1967, Friedman 1968, Lucas 1976, and Lucas and Sargent 1979, Samuelson did not regard the Phillips curve as immutable. He understood clearly that if the economy were always near full employment there would be something like Friedman's "natural rate of unemployment." In the classical world, the Phillips Curve would be 
a vertical line at the minimal unemployment level: $\mathrm{Q}$ would then always correspond to full employment, and $\mathrm{P}$ would float in free labor markets to whatever level that total money spending would determine. In a limiting model of depression unemployment, where wage rates were inflexible against any downward movements but where no costs ever rose until full employment was restored, the Phillips Curve would be the horizontal axis until minimal unemployment was reached, and it would then shoot up vertically. (S5-1961, 383)

Different countries would have different Phillips Curves "depending upon their institutional pattern and psychological outlooks" (383). The nub of the problem is this:

How can a mixed economy, without relying unduly on inefficient direct wage and price controls, give itself a Phillips Curve in which closer approaches to high employment can be made without engineering a considerable price creep? . . . This is truly an important, but terribly difficult, problem of the 1960s. (384)

By the eighth edition, the Phillips curve, which had been set apart in an appendix in the fifth, sixth, and seventh editions, is integrated fully into the main text. Samuelson acknowledges more clearly the instability of the Phillips curve, evidently acknowledging the turn of the profession toward the expectations-augmented Phillips curve and anticipating the Lucas critique: "We should reemphasize that economics is not an exact science. The data will not really fit any one Phillips Curve perfectly. More important still is the fact that the measured Phillips Curves represent short-term relationships which will shift in the longer run" (S8-1970, 811). A more detailed discussion of the role of expectations and the natural rate hypothesis are confined to a footnote $(821 \mathrm{n})$.

Although, as noted here, Samuelson mentions the idea of society giving itself a more favorable Phillips curve already in the fifth edition, the idea is left undeveloped until the ninth edition. Up to that point, the Phillips curve is treated principally as a description of the inflationary dilemma that faces the policy maker, who chooses among the feasible combinations of inflation and unemployment. Stagflation renewed Samuelson's interest in a better Phillips curve. The 45-degree diagram suggested that inflation and unemployment were mutually exclusive possibilities; stagflation suggested that the data did not agree. This meant abandoning parts of the earlier analysis. In the first edition, Samuelson 
had argued that monetary policy was ineffective; in subsequent editions, he had allowed monetary policy its day; now, in the ninth edition, he argues that both monetary and fiscal policies are effective only against demand-pull inflation and that incomes policy is essential (S9-1973, 363). For Samuelson, the problem became not to understand macroeconomic performance, but to change it: "How can a mixed economy supplement monetary and fiscal macro policy by an incomes policy designed to give itself a better Phillips Curve?" (833). Samuelson suggests three policies to improve the trade-off in the Phillips curve and to lower the natural rate of unemployment: (1) manpower training programs and improved labor market mechanisms; (2) reduction of discrimination against particular classes in the labor force, along with increased realism on the part of workers about employment opportunities; and (3) governmentsponsored "last resort" employment programs (836).

The other staples of the analysis of aggregate demand in intermediate macroeconomics textbook, Okun's law and the static aggregate-supply curve, do not appear in Economics until Samuelson is joined by his coauthor William Nordhaus in the twelfth edition. The introduction to this edition notes that all the major issues in macroeconomics will be analyzed using the aggregate-supply/aggregate-demand apparatus. The twelfth edition therefore marks the decisive break with the established Samuelsonian tradition.

Although the Phillips curve was an innovation relative to the first edition of Economics, Samuelson presented it as an extension or supplement to the core analytical apparatus, not as a replacement for it. The shifting policy problem, however, raised analytical challenges as well. Over the course of eleven editions in three decades, Samuelson moved from a confident assertion of the unity of modern economics to the acknowledgment of division and schism: "Solving one kind of problem often leads to emergence of a new kind of problem. The easy Keynesian victories against chronic depression are long behind us. As we shall see, the new phenomenon of 'stagflation' . . . poses grave new challenges for the mixed economy" (S11-1980, 223). As a result of the failure of the "new economics" to solve this problem, "vigorous debates now rage between different schools in macroeconomics" (309).

The bête noire of Samuelson's macroeconomics were the advocates of the quantity theory of money. In the first edition, Samuelson had been able to stigmatize quantity theorists as "monetary cranks." He struck a pose of scientific detachment--but one that presupposed the adequacy of his 
own account of income determination-and dismissed quantity theory as simply empirically incorrect because prices were not proportional to total spending and total spending was not proportional to the stock of money, as the crudest versions of the quantity theory suggest (S1-1948, 291).

Reacting to the revival of the quantity theory in the wake of Friedman's "Quantity Theory of Money: A Restatement" (1956), Samuelson is no longer so dismissive: "Since there has been something of a revival of interest in the quantity theory by a number of competent American economists [including Milton Friedman] in recent years, it is worth taking an eclectic approach here and reviewing the fundamentals of a sophisticated quantity theory approach" (S5-1961, 315). A sophisticated quantity theorist believes "that controlling the behavior of M[oney] will help much to control N[et]N[ational]P[roduct], for the reason that the resulting changes in V[elocity] will either be so small or so predictable as to make one confident that dollar NNP will still move in the same direction as M" (316). Confident of the neutrality of his framework and harmonist as always, Samuelson dismisses any further discussion of this theory, saying, "qualitatively, this is in agreement with almost any modern theory of income determination" (316).

A decade later, the eighth edition echoes the same position with respect to "monetarism," the nom de guerre of Friedman's quantity theory. Since the Great Depression,

the majority of experts think that monetary policy must be reinforced by stabilizing fiscal policies. But there is one important minority dissent to this view. A school called the 'monetarists,' originating at the University of Chicago and led by the able economist Professor Milton Friedman, believe $[s i c]$ that essentially everything that can be done to control macroeconomic aggregates-inflationary gaps and epochs of depression and slow growth-has to be done by control of the money supply alone. (S8-1970, 309)

Although monetarism represents an extreme view, Samuelson the scientist will not dismiss it: "After all, scientific truth could turn out to be on one extreme rather than in the middle" (309). However, "where monetarism differs from this so-called 'post-Keynesian neoclassical synthesis,' it is essentially wrong and indeed an extreme" (309).

Samuelson's treatment of monetarism represents a general strategy of finding the middle ground that goes back to the first edition. But, in the first edition, he regarded the problem largely as one of practical policy: 
use macroeconomics to get the economy to full employment and, then, classical microeconomics takes over. This position seemed, however, to confirm the common view that Keynesian economics was the economics of depression. From the beginning, Samuelson opposed this view. At first, he was content to point out that since there was a deflationary gap as well as an inflationary gap, the 45-degree apparatus was sufficiently general to address boom or slump (S3-1955, 241). As the analytical incapacities of the 45-degree diagram became clearer, Samuelson's focus shifted to the individual components of his model, while still appealing to neoclassical synthesis as the instrument of reconciliation.

The theory of interest rates provides a good example. The classical theory was that the interest rate was determined in the market for loanable funds. Changes in the level of real income shift the saving and investment curves, however, making the interest rate indeterminate. The classicals did not see this problem because "they had the comfortable view that chronic unemployment was impossible" (S3-1955, 560). Samuelson notes that the reader may question why such an "ancient (and irrelevant)" theory is still discussed. "Fifteen years ago, the author wouldn't have known quite what to say. But today one can give a confident reply" (569). The neoclassical synthesis allows redrawing the marginal efficiency schedule of investment, drawn up "given factors of expectation and technology and--most important-at the level of full employment assured by appropriate public tax and fiscal policies" (570).

As monetarism becomes a more important rival to Keynesian analysis, Samuelson modifies his strategy, stressing less that his post-Keynesian policy prescriptions are the middle ground and more that the analytical apparatus is neutral and general, so that alternative views all represent special cases. In the fifth edition, he writes:

Classical views that there can never be unemployment and depression versions of the Keynesian system will turn out to be alternative poles of such an analysis; and what most economists would consider to be the most realistic description of how our economy works and what are the potencies of policy weapons will fall somewhere on the continuum between these extreme poles. (S5-1961, 377)

Generality is again seen in the individual components of the model. Those who believe in the ineffectiveness of monetary policy in a depression will make the schedule of liquidity-preference horizontal, while those who believe in an effective monetary policy would make it vertical. Similarly 


\section{Kerry A. Pearce and Kevin D. Hoover}

with the schedule of the marginal efficiency of investment:

A 'deep depression' pessimist will pencil in an almost vertical schedule: so depressed are investment opportunities believed to be then, ... that lowering $i$ practically to zero will have little reviving effects. Alternatively, a classical optimist who thinks monetary policy has great potency will . . . pencil in an almost horizontal marginal efficiency schedule: for him the road to high employment and to zero inflationary gap is an easy one. (378)

Instead of the chain Money $\Rightarrow$ Interest Rates $\Rightarrow$ Investment $\Rightarrow$ Net National Product, sophisticated quantity theorists prefer Money $\Rightarrow$ Money $x$ Velocity $\Rightarrow$ Net National Product. But this latter chain "asserts that an increase in $\mathrm{M}$, unless offset fully by an induced shift in V of the type that neither they nor the believers in the four-link chain consider likely, will serve to increase dollar NNP" (S5-1961, 379). Although "these different modes of language ... formally represent the same facts . . those who prefer one terminology usually think that certain hypotheses about the real world are more fruitful than certain other ones" (380). The bulk of economists "incline toward the [four-link-chain] view, [but] there is no need to be dogmatic about the matter" (380).

It is in the context of his increasing stress on the generality of the theoretical framework that Samuelson gradually introduces the IS-LM model into Economics (S3-1955, 580). The diagram is first introduced in an appendix to the third edition, attributed equally to Hicks and Hansen. The IS curve is called the BB curve; the LM curve is called the MM curve. By the seventh edition, the IS-LM diagram, "the Hicks-Hansen" synthesis, is used in the analysis of inflation (S7-1967, 330). The LM curve is used to assert the generality of the analytical framework. It is drawn nearly horizontal at low levels of income (depression model or "liquidity trap" pole) and nearly vertical at high levels (classical model) (331). Samuelson notes that the depression model is sometimes called the Keynesian model, "but most authorities agree that this is bad terminology, since Keynes' General Theory covered all cases from the beginning and not merely that of the Great Depression" (331n).

The ultimate expression of the neutrality of the IS-LM framework comes in the ninth edition. Samuelson dismisses the monetarist movement as a minor aside, and no threat to the Keynesian model:

The Hicks-Hansen diagram [IS-LM] . . succeeds in synthesizing 
fiscal and monetary policy, the theory of income determination, and the theory of macroeconomics by providing a definite and general theory of the velocity of $\mathrm{M}$. Thus the monetarist counterrevolution reduces to debate about the shapes of LM and IS. (S9-1973, 352) ${ }^{18}$

The IS-LM model is never held up as an alternative to the 45-degree diagram. Although he does not provide a derivation of the former from the latter, Samuelson believes that they are alternative ways of presenting the same underlying model. And the IS-LM model is always held to a subordinate role. Over time, it plays a somewhat more important part: first because over the sequence of editions of Economics a richer collection of factors is seen to be macroeconomically important; second because the IS-LM model is better adapted to make Samuelson's point about the generality of Keynesian analysis. In adopting it, however, Samuelson adds nothing that was not available to the sophisticated economist of 1948.

In the eleventh edition, Samuelson is forced to concede that even the new wonder-weapon of IS-LM was not enough to convince the profession of the neutrality and unity of the Keynesian model. The persistence of the problem of stagflation presents a theoretical as well as a policy challenge. As a result of the failure of the "new economics" to cure stagflation, "vigorous debates now rage between different schools in macroeconomics" (S11-1980, 309). Macroeconomics had become riven with schism and sects. In the face of these divisions, Samuelson nevertheless stands not just as a voice of orthodoxy, but perpetually as the voice of harmony and scientific neutrality: "To understand the challenges offered by monetarists and believers in 'rational expectations,' you will first need to understand the fundamentals of income analysis" (196).

\section{Reformation and Disestablishment}

Our analysis of the Keynesian model in Samuelson's Economics ends in 1980 with the eleventh edition, the last one in which Samuelson is

18. Milton Friedman (1974, 137-38) argues, correctly, that the main tenets of his monetarism cannot be reduced to assumptions about the slopes of the IS-LM curves. The real issue between the monetarists and the Keynesians come down to two issues. First, the shape of the aggregate supply curve: essentially, is it possible to have prolonged underemployment? The monetarists take the classical view that the natural tendency of the economy is to return to full employment. Second, the causal priority of money over nominal income. Neither the 45-degree diagram nor the IS-LM diagram, since both are comparative static apparatuses, is suited to address this issue. 
the sole author. ${ }^{19}$ Macroeconomics for the decade before and the decade and a half after that date continues to be in ferment-a period not unlike the 1920s and 1930s before Keynes wrote The General Theory. Macroeconomics textbooks continue, by and large, to be Keynesian. Introductory textbooks can be rightly viewed as the progeny of Samuelson's Economics, typically stressing the same 45-degree apparatus that Economics has featured for over forty years. Intermediate textbooks typically stress the IS-LM presentation, supplemented with an aggregate supply analysis and a Phillips curve. The analytical apparatus of these textbooks is no longer closely associated with any particular policy. The analytical uniformity of American textbooks and the policy neutrality of their analytical machinery is one of Samuelson's central achievements, for, although he always advocated certain policies, his emphasis on scientific economics drove a wedge between those policies and positive economics. Samuelson's work is thus the triumph of normal science.

But four decades of normal science in macroeconomics may well be passed. The current scene is littered with inchoate alternatives and schools that stand in self-conscious opposition to Keynesian analysis on both the policy and the analytical fronts. Some people see the advent of the New Classical Macroeconomics as a revolution parallel to the Keynesian revolution (Hoover 1988, 1993). If that is so, the new revolution awaits its Samuelson. The existing new classical textbooksSargent 1987 at the graduate level and Barro 1993 at the undergraduate level-play roles similar to those played by the textbooks of Boulding and Tarshis. The new classical revolution has yet to be formulated in a textbook that could dominate the market and be sincerely flattered with the imitation of most other texts. If the New Classical Macroeconomics is a scientific revolution, its period of normal science has yet to be firmly established.

\section{References}

Barro, Robert. 1993. Macroeconomics. New York: Wiley.

Baumol, William J., and Alan S. Blinder. 1991. Economics: Principles and Policy.

19. It would have bcen interesting, as Allin Cottrell among others have urged, to consider the editions in which William Nordhaus is Samuelson's coauthor. The first of these editions, the twelfth, is a decisive break with the first eleven editions, joining the analytic tradition of the forty-five-degree diagram firmly with the IS-LM tradition. To do justice to this alternative tradition would require far more than the available space. 
New York: Harcourt Brace Jovanovich.

Benham, Frederic, and Francis Boddy. 1947. Principles of Economics. New York: Pitman.

Blaug, Mark. 1991. Second Thoughts on the Keynesian Revolution. HOPE 23. 2: 171-81.

Boland, Lawrence A. 1989. The Methodology of Economic Model Building: Methodology after Samuelson. London: Routledge.

Boulding, Kenneth. 1948. Economic Analysis. 2d ed. New York: Harper.

Buckley, William F. 1951. God and Man at Yale. Chicago: Henry Regnery.

Carlson, Valdemar. 1946. An Introduction to Modern Economics. Philadelphia: Blakiston.

Clarke, Peter. 1988. The Keynesian Revolution in the Making, 1924-1936. Oxford: Clarendon.

Clower, Robert. 1965. The Keynesian Counterrevolution. In The Theory of Interest Rates. Edited by Frank Hahn and F. P. R. Brechling. London: Macmillan.

Coddington, Alan. 1983. Keynesian Economics: The Search for First Principles. London: Allen \& Unwin.

Colander, David. 1984. Was Keynes a Keynesian or a Lernerian? Journal of Economic Literature 22 (December): 1571-79.

Davidson, Paul. 1989. Patinkin's Interpretation of Keynes and the Keynesian Cross. HOPE 21.3:549-53.

Dornbusch, Rudiger, and Stanley Fischer. 1994. Macroeconomics. 6th ed. New York: McGraw-Hill.

Elzinga, Kenneth G. 1992. The Eleven Principles of Economics. Southern Economic Journal 58 (April): 861-79.

Franklin, Fabian. 1936. Keynes's Economics. Saturday Review 13 (April 4): 32-33.

Friedman, Milton. 1953. The Methodology of Positive Economics. In Essays in Positive Economics. Chicago: University of Chicago Press.

- 1956. The Quantity Theory of Money: A Restatement. In Studies in the Quantity Theory of Money: Edited by Milton Friedman. Chicago: University of Chicago Press.

- 1957. A Theory of the Consumption Function. Princeton: Princeton University Press.

1968. The Role of Monetary Policy. American Economic Review 58 (January): $1-17$.

- 1974. A Theoretical Framework for Monetary Analysis. In Milton Friedman's Monetary Framework: A Debate with His Critics. Edited by Robert J. Gordon. Chicago: University of Chicago Press.

Fusfeld, Daniel R. 1985. Keynes and the Keynesian Cross: A Note. HOPE 17.3:38589.

Garver, Frederic, and Alvin H. Hansen. 1937. Principles Of Economics. 2d ed. Boston: Ginn.

. 1947. Principles Of Economics. 3d ed. Boston: Ginn.

Gordon, Robert J. 1993. Macroeconomics. 6th ed. New York: HarperCollins. 


\section{Kerry A. Pearce and Kevin D. Hoover}

Hall, Robert E., and John B. Taylor. 1993. Macroeconomics. 4th ed. New York: Norton.

Hansen, Alvin H. 1936a. Mr. Keynes on Underemployment Equilibrium. Journal of Political Economy 44 (December): 667-86.

— 1936b. Under-employment Equilibrium. Yale Review 25 (Summer): 82830.

1938. Keynes on Underemployment Equilibrium. In Full Recovery or Stagnation. London: A. \& C. Black.

- 1949. Monetary Theory and Fiscal Policy. New York: McGraw-Hill.

. 1951. Business Cycles and National Income. New York: Norton.

- 1953. A Guide to Keynes. New York: McGraw-Hill.

Hardy, Charles O. 1936. Review of The General Theory of Employment, Interest and Money, by John Maynard Keynes. American Economic Review 26 (Spring): 490-93.

Hicks, John R. [1937] 1967. Mr. Keynes and the Classics. In Critical Essays in Monetary Theory. Oxford: Clarendon.

Hoover, Kevin D. 1988. The New Classical Macroeconomics: A Sceptical Inquiry. Oxford: Basil Blackwell.

. 1993. The Rational Expectations Revolution: An Assessment. Cato Journal 121 (Spring/Summer): 81-96.

Ise, John. 1950. Economics. New York: Harper.

Keynes, John Maynard. 1936. The General Theory of Employment, Interest and Money. London: Macmillan.

1937. The General Theory of Employment. Quarterly Journal of Economics 52 (February): 209-23.

King, J. E. 1993. Aggregate Supply and Demand Analysis since Keynes: A Partial History. Paper presented at the Malvern Conference on Political Economy, Great Malvern, England. August.

Klein, Lawrence R. 1947. The Keynesian Revolution. New York: Macmillan.

Kuhn, Thomas. 1962. The Structure of Scientific Revolutions. Chicago: University of Chicago Press.

Lederer, Emil. 1936. Commentary on Keynes. Social Research 3:478-87.

Leijonhufvud, Axel. 1966. On Keynesian Economics and the Economics of Keynes. New York: Oxford.

Lindbeck, Assax. 1985. The Prize in Economic Science in Honor of Alfred Nobel. Journal of Economic Literature 23 (March): 37-56.

Lipsey, Richard G., Paul N. Courant, Douglas D. Purvis, and Peter O. Steiner. 1993. Economics. 10th ed. New York: HarperCollins.

Lucas, R. E. Jr. 1976. Econometric Policy Evaluation: A Critique. In The Phillips Curve and Labor Markets. Edited by K. Brunner and A. H. Meltzer. CarnegieRochester Conference Series on Public Policy, vol. 1. Amsterdam: North-Holland.

Lucas, Robert E. Jr., and Thomas J. Sargent. [1979] 1981. After Keynesian Macroeconomics. In Rational Expectations and Econometric Practice. Edited by Robert E. Lucas Jr. and Thomas J. Sargent. London: Allen \& Unwin. 
McConnell, Campbell R. 1987. Economics. 10th ed. New York: McGraw-Hill.

McKenna, Joseph. 1955. Aggregate Economic Analysis. New York: RinehartWinston.

Meyers, Albert L. [1941] 1948. Elements of Modern Economics. 3d ed. New York: Prentice-Hall.

Miller, Merton H., and Charles W. Upton. 1974. Macroeconomics: A Neoclassical Introduction. Homewood, Ill.: Irwin.

Modigliani, Franco. 1944. Liquidity Preference and The Theory of Interest of Money. Econometrica 12 (January): 44-88.

Patinkin, Don. 1956. Money, Interest and Prices. New York: Harper \& Row. 1983. Paul Samuelson's Contribution to Monetary Economics. In Paul Samuelson and Modern Economic Theory. Edited by E. Cary Brown and Robert M. Solow. New York: McGraw-Hill.

. 1989. Keynes and the Keynesian Cross: A Further Note, with a Reply by Daniel R. Fusfeld. HOPE 21.3:537-47. Phelps, Edmund S. 1967. Phillips Curves, Expectations of Inflation and Optimal Unemployment over Time. Economica, n.s., 34 (August): 254-81.

Phillips, A. W. 1958. The Relation between Unemployment and the Rate of Change of Money Wages in the United Kingdom 1961-1957. Economica, n.s., 25 (November): 283-99.

Robinson, Joan. 1962. Review of Money, Trade and Economic Growth by H. G. Johnson. Economic Journal 72 (September): 690-92.

Samuelson, Paul A. 1939a. Interactions between the Multiplier Analysis and the Principle of Acceleration. Review of Economic Statistics 21:75-78.

- 1939b. A Synthesis of the Principle of Acceleration and the Multiplier. Journal of Political Economy 47 (December): 786-97.

. 1947. Foundations of Economic Analysis. Cambridge: Harvard University Press.

. 1948-80. Economics. 1st ed. 1948; 2d ed. 1951; 3d ed. 1955; 4th ed. 1958; 5th ed. $1961 ; 6$ th ed. $1964 ; 7$ th ed. $1967 ; 8$ th ed. $1970 ; 9$ th ed. $1973 ; 10$ th ed. 1976; 11 th ed. 1980. New York: McGraw-Hill. (Cited within text as S[edition no.]-[publication date].)

_ 1966-86. The Collected Scientific Papers of Paul A. Samuelson. Cambridge: MIT Press.

Samuelson, Paul A., and William D. Nordhaus. 1985-92. Economics. 12th ed. 1985; 14th ed. 1992. New York: McGraw-Hill. (cited within text as S12-1985-92)

Samuelson, Paul A., and Robert M. Solow. 1960. Analytical Aspects of Anti-inflation Policy. American Economic Review 50 (May): 177-94.

Sargent, Thomas J. 1987. Macroeconomic Theory. 2d ed. Orlando: Academic Press. Scitovsky, Tibor. 1984. Lerner's Contribution to Economics. Journal of Economic Literature 22 (December): 1547-71.

Stewart, Maxwell S. 1936. The Mainsprings Of Capitalism. Nation 142 (April 15): 485-86.

Tarshis, Lorie. 1947. The Elements of Economics. New York: McGraw-Hill. 


\section{Kerry A. Pearce and Kevin D. Hoover}

Taylor, Horace. 1936. Mr. Keynes's General Theory. New Republic 86 (April 29): 349.

Tobin, James. 1958. Liquidity Preference as Behavior towards Risk. Review of Economic Statistics 25 (February): 65-86.

Weintraub, E. Roy. 1991. Stabilizing Dynamics: Constructing Economic Knowledge. New York: Cambridge University Press.

Young, Warren. 1987. Interpreting Mr. Keynes. Cambridge, U.K.: Polity. 